\title{
Pengembangan Perangkat Pembelajaran Matematika SMP dengan Pendekatan Brain Based Learning Berorientasi Pada Kemampuan Koneksi Matematis
}

\author{
Ainun Fitriani $^{1)^{*}}$, Ewan $\operatorname{Irawan}^{1)}$ \\ ${ }^{1}$ STKIP Taman Siswa Bima \\ aainunfitriani7@gmail.com
}

Abstrak: Penelitian pengembangan ini bertujuan untuk menghasilkan perangkat pembelajaran matematika SMP dengan pendekatan Brain Based Learning (BBL) berorientasi pada kemampuan koneksi matematis siswa yang berkualitas baik, berdasarkan aspek kevalidan, kepraktisan, dan keefektifan. Penelitian ini menggunakan model pengembangan ADDIE yang meliputi tahap analysis, design, development, implementation, evaluation. Sebanyak 23 siswa di kelas $\mathrm{VII}^{8}$ MTs Negeri 2 Kota Bima yang dijadikan subyek penelitian. Instrumen penelitian yang digunakan adalah lembar kevalidan, lembar penilaian guru, lembar penilaian siswa, lembar observasi keterlaksanaan pembelajaran, dan tes kemampuan koneksi matematis. Analisis data kevalidan, kepraktisan, dan keefektifan dilakukan dengan mengkonversi skor aktual menjadi data kualitatif. Hasil penelitian ini berupa perangkat pembelajaran matematika SMP dengan pendekatan Brain Based Learning (BBL) yaitu RPP dan LKS. Kualitas kevalidan berdasarkan penilaian validator menunjukkan bahwa perangkat pembelajaran yang dikembangkan telah memenuhi kriteria valid dengan rata-rata skor untuk RPP sebesar 193 (sangat baik) dan untuk LKS sebesar 114 (baik). Kualitas kepraktisan menunjukkan bahwa perangkat pembelajaran yang dikembangkan telah memenuhi kriteria praktis dengan skor berdasarkan penilaian guru sebesar 74 (sangat baik), penilaian siswa 38,78 (baik), dan persentase keterlaksanaan pembelajaran sebesar 94\% (sangat baik). Kualitas keefektifan menunjukkan bahwa perangkat pembelajaran yang dikembangkan telah memenuhi kriteria efektif dengan rata-rata persentase ketuntasan tes kemampuan koneksi matematis sebesar 75\% (baik).

Kata Kunci: Perangkat Pembelajaran, Brain Based Learning, Kemampuan Koneksi Matematis

\section{Pendahuluan}

Pendidikan menurut Undang-undang Nomor 20 Tahun 2003 merupakan usaha sadar dan terencana untuk mewujudkan suasana belajar dan proses pembelajaran agar peserta didik secara aktif mengembangkan potensi dirinya yang diperlukan oleh dirinya, masyarakat, bangsa, dan negara. Faktanya, perwujudan suasana belajar ataupun proses pembelajaran seperti itu belum berjalan secara maksimal, sehingga dapat dikatakan bahwa kualitas mutu pendidikan di Indonesia masih rendah khususnya pada pembelajaran matematika (Fitriani, 2019). Suatu pendidikan akan berhasil apabila proses pembelajaran memberikan makna belajar bagi setiap individu. Pembelajaran matematika menekankan pada pembelajaran menggunakan manipulasi dan membuat koneksi dengan representasi untuk siswa memahami matematika pada tingkat abstrak (Furner, J.M \& Marinas, 2013).

Adanya koneksi dapat memberikan makna dalam pembelajaran dan memberikan alasan kepada siswa untuk belajar (Johnson, 2010, p.6). kemampuan koneksi matematika adalah kemampuan untuk memecahkan persoalan-persoalan matematika yang memiliki kaitan terhadap materi yang dipelajari sebelumnya (Linto et al., 2012). selain itu, (Lestari, 2014) menyatakan bahwa kemampuan koneksi matematis merupakan kemampuan dalam mengaitkan konsep-konsep matematika baik antar konsep itu sendiri maupun mengaitkan konsep matematika dengan bidang lain. Jadi siswa perlu memiliki kemampuan koneksi matematis karena koneksi adalah inti dari pembelajaran. (Rohendi \& Dulpaja, 2013) juga berpendapat bahwa kemampuan koneksi matematika adalah salah satu tujuan pembelajaran yng sangat berguna bagi siswa karena topik matematika saling terkait satu sama lain.

Berdasarkan hasil observasi yang dilaksanakan di MTs Negeri 2 Kota Bima, menunjukkan bahwa kemampuan koneksi matematis peserta didik belum optimal dikarenakan kurangnya kemampuan peserta didik dalam mengaitkan beberapa konsep matematis. Peserta didik juga masih cenderung pasif yang menyebabkan 
kurang terlibatnya dalam proses pembelajaran, hal tersebut dapat menyebabkan pembelajaran matematika kurang bermakna. Selain itu, perangkat pembelajaran yang mengakomodasi kemampuan koneksi matematis belum tersedia. Sehingga dibutuhkan sebuah model pembelajaran yang efektif digunakan untuk meningkatkan kemampuan koneksi matematis peserta didik.

Model Brain Based Learning (BBL) dapat menjadi pilihan yang bagus untuk menangani masalah tantangan pembelajaran peserta didik. Karena unsur utama dalam model Brain Based Learning (BBL) adalah pembelajaran dengan masalah nyata yang dapat mengurangi kejenuhan peserta didik sehingga membuat peserta didik merasa bahwa pembelajaran matematika tidak selalu bersifat abstrak dan mampu diaplikasikan dalam kehidupan seharihari (Fitriani, 2019).

Brain Based Learning (BBL) merupakan pemmbelajaran berbasis otak dimana otak erat kaitannya dalam perkembangan kognitif (Klinek \& Indiana, 2009, p.11). (Siercks, 2012, p.3) juga berpendapat bahwa BBL didasarkan pada gagasan bahwa setiap bagian otak memiliki fungsi tertentu ketika berhubungan dengan pembelajaran. BBL juga dapat dicapai dalam keadaan aktif, kondisi tegang yang rendah, dan memiliki gaya belajar yang unik untuk mempermudah asimilasi pengetahuan baru (Bowen, 2011). Pembelajaran tanpa memperhatikan bagaimana otak belajar dapat diibaratkan seperti mendesain sarung tangan namun tidak mengetahui seperti apa bentuk dan langkah-langkahnya (Kaur, 2013).

Pembelajaran berbasis otak telah dihasilkan dari pendidik dan peneliti yang menerapkan temuan dari penelitian tentang otak untuk memandu praktik mengajar (Kapadia, 2014). Konsep Brain Based Learning (BBL) yang disajikan dengan contoh aplikasi dalam pendidikan, yaitu membangun atas dasar pengetahuan siswa saat ini, pengajaran dalam konsep, mengajar untuk pertransferan, membuat pelajaran pribadi termasuk emosi, menggunakan pembelajaran kinestik, menyeimbangkan tantangan dan stress, dan menciptakan lingkungan belajar yang menarik (Craig, 2007). Aspek BBL adalah neurologis, emosional, dan lingkungan (Connell, 2009) Tujuan penelitian ini adalah untuk menghasilkan perangkat pembelajaran matematika SMP dengan pendekatan Brain Based Learning (BBL) berorientasi pada kemampuan koneksi matematis siswa yang berkualitas baik, berdasarkan aspek kevalidan, kepraktisan, dan keefektifan.

\section{Metode}

Penelitian ini menggunakan penelitian R \& D (Research and Development) dengan model ADDIE yang meliputi tahap analysis, design, development, implementation, dan evaluation. Penelitian ini bertujuan untuk mengembangkan dan mengetahui kualitas perangkat pembelajaran matematika berupa RPP dan LKS dengan pendekatan Brain Based Learning (BBL) berdasarkan aspek kevalidan, kepraktisan, dan keefektifan ditinjau dari kemampuan koneksi matematis. Penelitian ini dilaksanakan di semester genap Tahun Ajaran 2019/2020 pada siswa kelas VII8 MTs Negeri 2 Kota Bima.

\section{Prosedur Penelitian}

Prosedur pengembangan pada penelitian ini terdiri dari lima tahapan yaitu analisis, perancangan, pengembangan, implementasi, dan evaluasi. Tahap analisis adalah tahap pra perencanaan pengembangan produk berupa perangkat pembelajaran matematika dengan pendekatan BBL. Pada tahap ini peneliti menganalisis hal-hal yang berkaitan dengan pengembangan perangkat pembelajaran, diantaranya analisis kebutuhan, analisis karakteristik siswa, dan analisis materi; Tahap perancangan bertujuan untuk mempersiapkan segala hal yang dibutuhkan dalam pengembangan perangkat pembelajaran, diantaranya RPP dan LKS; Tahap pengembangan bertujuan untuk mengembangkan produk berupa RPP dan LKS; Tahap implementasi merupakan langkah peneliti untuk mengujicobakan perangkat pembelajaran; Tahap evaluasi merupakan langkah peneliti mengevaluasi hal yang terkait dengan pengembangan perangkat pembelajaran berdasarkan hasil uji coba di lapangan.

\section{Teknik dan Instrumen Pengumpulan Data}

Dalam penelitian ini teknik pengumpulan data berupa tes kemampuan koneksi matematis, angket penilaian guru dan siswa, dan lembar observasi keterlaksanaan pembelajaran. Untuk instrumen pengumpulan data yang digunakan untuk mendapatkan data tentang kevalidan, kepraktisan, dan keefektifan, berupa lembar validasi, lembar penilaian guru, lembar penilaian siswa, lembar observasi keterlaksanaan pembelajaran, dan tes kemampuan koneksi matematis. Adapun rincian masing-masing instrumen adalah sebagai berikut: Instrumen 
kevalidan meliputi lembar validasi RPP dan LKS; Instrumen kepraktisan meliputi lembar penilaian guru, lembar penilaian siswa, dan lembar observasi keterlaksanaan pembelajaran; Instrumen keefektifan meliputi tes kemampuan koneksi matematis.

\section{Teknik Analisis Data}

Teknik analisis data dilakukan untuk mendapatkan perangkat pembelajaran dengan pendekatan BBL yang berkualitas dan memenuhi aspek kevalidan, kepraktisan, dan keefektifan. Data yang terkumpul selanjutnya dianalisis. Untuk analisis data kevalidan dan kepraktisan, data kuantitatif diubah menjadi data kualitatif dengan skala lima

\section{Hasil dan Pembahasan}

\section{Tahap Analisis (Analysis)}

Pada tahap analisis kebutuhan peneliti melakukan observasi pra penelitian. Berdasarkan hasil observasi diketahui bahwa pembelajaran yang dilakukan masih berpusat pada guru. Guru lebih banyak menerangkan materi kemudian memberi contoh soal. Setelah itu, guru memberikan latihan soal kepada siswa yang tidak jauh berbeda dari soal yang dicontohkan. Berdasarkan kondisi tersebut, terlihat bahwa pembelajaran di kelas belum mengembangkan kemampuan koneksi matematis, sehingga diperlukan perangkat pembelajaran yang dapat mengembangkan kemampuan koneksi matematis.

Pada tahap analisis karakteristik siswa dilakukan dengan mengidentifikasi karakter siswa yang akan menggunakan perangkat pembelajaran. Identifikasi karakter siswa dilakukan melalui observasi di kelas dan wawancara dengan guru matematika kelas tersebut. Berdasarkan hasil observasi diketahui bahwa siswa cenderung pasif dalam pembelajaran dan guru juga belum mengembangkan pembelajaran yang berorientasi pada kemampuan koneksi matematis.

Analisis materi dilakukan dengan menentukan materi yang digunakan dalam penelitian. Adapun materimateri pada perangkat pembelajaran yang dikembangkan meliputi nilai keseluruhan, nilai per-unit, nilai sebagian, harga pembelian, harga penjualan, diskon, bruto, tara, netto, bunga tunggal, dan pajak.

\section{Tahap Perancangan (Design)}

Tahap perancangan merupakan tahapan selanjutnya setelah tahap analisis kebutuhan, karakteristik siswa, dan analisis materi dilakukan. Tahapan ini berisi kegiatan penyusunan perangkat pembelajaran yang menggunakan pendekatan BBL berupa Rencana Pelaksanaan Pembelajaran dan Lembar Kerja Siswa.

\section{Tahap Pengembangan (Development)}

Pada tahap ini, peneliti mengembangkan perangkat pembelajaran berdasarkan rancangan yang telah direncanakan. Perangkat pembelajaran yang dikembangkan berupa RPP dan LKS yang terdiri dari nilai keseluruhan, nilai per-unit, nilai sebagian, harga pembelian, harga penjualan, diskon, bruto, tara, netto, bunga tunggal, dan pajak.

\section{Tahap Implementasi (Implementation)}

Pada tahap ini, perangkat pembelajaran yang telah dikembangkan selanjutnya diujicobakan dalam pembelajaran di kelas. Uji coba dilaksanakan sebanyak enam kali pertemuan dan ditambah dua kali pertemuan untuk dilakukan tes koneksi matematis.

\section{Tahap Evaluasi (Evaluation)}

Pada tahap evaluasi ini menghasilkan data untuk menganalisis aspek kepraktisan dan keefektifan perangkat pembelajaran. Data kepraktisan perangkat pembelajaran diperoleh dari hasil penilaian guru dan penilaian siswa serta persentase keterlaksanaan pembelajaran. Untuk aspek keefektifan dilihat dari hasil tes kemampuan koneksi matematis siswa.

\section{Hasil Uji Coba Produk}

Perangkat pembelajaran yang telah dikembangkan selanjutnya dinilai aspek kevalidannya menggunakan validasi ahli. Validasi dalam penelitian ini melibatkan dua orang validator, penilaian yang diberikan oleh kedua 
validator menyatakan bahwa perangkat pembelajaran yang dikembangkan valid sehingga layak digunakan untuk uji coba dilapangan.

\section{Rencana Pelaksanaan Pembelajaran (RPP)}

Penilaian RPP yang dilakukan oleh validator berdasarkan aspek-aspek yang terdapat pada RPP, meliputi: identitas mata pelajaran, kegiatan pembelajaran, kesesuaian media dan sumber belajar, penilaian hasil belajar, dan penggunaan bahasa. Adapun data hasil valiadasi RPP tiap aspek dapat dilihat pada Tabel 1 dan penilaian RPP tiap validator dapat dilihat pada Tabel 2 sebagai berikut.

Tabel 1. Penilaian RPP Tiap Aspek

\begin{tabular}{clccc}
\hline No. & \multicolumn{1}{c}{ Aspek Yang Dinilai } & $\begin{array}{c}\text { Rata-Rata } \\
\text { Skor }\end{array}$ & $\begin{array}{c}\text { Skor } \\
\text { Maksimal }\end{array}$ & Kategori \\
\hline 1. & Identitas Mata Pelajaran & 10 & 10 & Sangat Baik \\
2. & Rumusan Indikator Dan Tujuan & 17,5 & 20 & Sangat Baik \\
3. & Kesesuaian Materi & 23,5 & 30 & Baik \\
4. & Pendekatan Pembelajaran & 31,5 & 35 & Sangat Baik \\
5. & Kegiatan Pembelajaran & 58 & 65 & Sangat Baik \\
6. & Kesesuaian Media Dan Sumber Pembelajaran & 13 & 15 & Sangat Baik \\
7. & Penilaian Hasil Belajar & 18,5 & 20 & Sangat Baik \\
8. & Penggunaan Bahasa & 17,5 & 20 & Sangat Baik \\
\hline
\end{tabular}

Tabel 2. Penilaian RPP Tiap Validator

\begin{tabular}{ccccc}
\hline No. & Validator & Total Skor & Kategori & Keterangan \\
\hline 1. & I & 184 & Sangat Baik & Layak Digunakan \\
2. & II & 202 & Sangat Baik & Layak Digunakan \\
\hline & Rata-Rata & 193 & \multicolumn{2}{c}{ Sangat Baik } \\
\hline
\end{tabular}

Berdasarkan penilaian validator mengenai RPP diketahui bahwa RPP yang dikembangkan telah valid dengan kategori sangat baik sehingga layak untuk diujicobakan di lapangan.

\section{Lembar Kegiatan Siswa (LKS)}

Penilaian LKS yang dilakukan oleh validator berdasarkan aspek-aspek yang meliputi: keseuaian dengan pendekatan BBL, kesesuaian dengan kemampuan koneksi matematis, kesesuaian isi dan materi, pengaturan tata letak LKS, kesesuaian dengan komponen kebahasan, kesesuaian komponen penyajian, dan manfaat atau kegunaan LKS. Adapun data hasil validasi penilaian LKS tiap aspek dapat dilihat pada Tabel 3 dan penilaian LKS tiap validator dapat dilihat pada Tabel 4 sebagai berikut.

Tabel 3. Penilaian LKS Tiap Aspek

\begin{tabular}{clccc}
\hline No. & \multicolumn{1}{c}{ Aspek yang dinilai } & $\begin{array}{c}\text { Rata-rata } \\
\text { Skor }\end{array}$ & $\begin{array}{c}\text { Skor } \\
\text { Maksimal }\end{array}$ & Kategori \\
\hline 1. & kesesuaian dengan pendekatan BBL & 26,5 & 30 & Sangat Baik \\
2. & kesesuaian dengan kemampuan koneksi matematis & 9 & 10 & Sangat Baik \\
3. & kesesuaian isi dan materi & 22 & 25 & Sangat Baik \\
4. & pengaturan tata letak LKS & 11 & 15 & Baik \\
5. & kesesuaian dengan komponen kebahasan & 16 & 20 & Sangat Baik \\
6. & kesesuaian komponen penyajian & 16 & 20 & Sangat Baik \\
7. & manfaat atau kegunaan LKS & 13,5 & 15 & Sangat Baik \\
\hline
\end{tabular}

Tabel 4. Penilaian LKS Tiap Validator

\begin{tabular}{ccccc}
\hline No. & Validator & Total Skor & Kategori & Keterangan \\
\hline 1. & I & 106 & Baik & Layak Digunakan dengan Revisi \\
2. & II & 122 & Sangat Baik & Layak Digunakan \\
\hline & Rata-Rata & 114 & & Baik \\
\hline
\end{tabular}


Berdasarkan penilaian validator mengenai LKS diketahui bahwa LKS yang dikembangkan telah valid dan memenuhi kategori baik sehingga layak untuk diujicobakan di lapangan.

\section{Uji Coba Lapangan}

Uji coba lapangan yang dilaksanakan bertujuan untuk memperoleh data mengenai kepraktisan dan keefektifan perangkat pembelajaran matematika dengan pendekatan BBL yang berorientasi pada kemampuan koneksi matematis siswa. Penilaian kualitas berdasarkan aspek kepraktisan diantaranya penilaian guru, penilaian siswa, dan persentase keterlaksanaan pembelajaran. Sedangkan penilaian kualitas keefektifan dari produk pengembangan didasarkan pada hasil tes kemampuan koneksi matematis siswa.

\section{Analisis Data Penilaian Guru}

Adapun penilaian yang diberikan oleh guru terhadap perangkat pembelajaran yang terdiri dari RPP dan LKS dapat dilihat pada Tabel 5 berikut.

Tabel 5. Hasil Penilaian Guru

\begin{tabular}{cccc}
\hline No. & Perangkat & Skor & Kategori \\
\hline 1. & RPP & 34 & Sangat Baik \\
2. & LKS & 40 & Sangat Baik \\
\hline & Rata-Rata & 74 & Sangat Baik \\
\hline
\end{tabular}

Berdasarkan tabel di atas diketahui bahwa hasil penilaian guru terhadap perangkat pembelajaran berupa RPP dan LKS yang dikembangkan terdapat pada kategori sangat baik. Dengan demikian perangkat pembelajaran tersebut dapat dikatakan praktis.

\section{Analisis Data Penilaian Siswa}

Adapun penilaian yang diberikan oleh siswa terhadap perangkat pembelajaran yang berupa LKS dapat dilihat pada Tabel 6. Berdasarkan nilai rata-rata penilaian siswa pada tabel di atas diketahui bahwa perangkat pembelajaran berupa LKS yang dikembangkan terdapat pada kategori baik. Dengan demikian perangkat pembelajaran tersebut dapat dikatakan praktis.

\section{Analisis Data Hasil Observasi Keterlaksanaan Pembelajaran}

Analisis ini dilakukan untuk mengetahui keterlaksanaan langkah-langkah pembelajaran dengan menggunakan pendekatan BBL yang disusun berdasarkan RPP yang telah dikembangkan. Adapun hasil observasi dapat dilihat pada Tabel 7.

Tabel 6. Persentase Penilaian Siswa

\begin{tabular}{lcc}
\hline \multicolumn{1}{c}{ Interval Skor } & Kategori & Persentase \\
\hline$X>42$ & Sangat Baik & $9 \%$ \\
$34<X \leq 42$ & Baik & $74 \%$ \\
$26<X \leq 34$ & Cukup Baik & $17 \%$ \\
$18<X \leq 26$ & Kurang Baik & $0 \%$ \\
$X \leq 18$ & Sangat Kurang & $0 \%$ \\
\hline Rata-Rata & \multicolumn{2}{c}{38,78 (Baik) } \\
\hline
\end{tabular}

Tabel 7. Hasil Observasi Keterlaksanaan Pembelajaran

\begin{tabular}{ccc}
\hline Pertemuan ke- & Persentase & Kategori \\
\hline 1 & $78 \%$ & Baik \\
2 & $89 \%$ & Sangat Baik \\
3 & $94 \%$ & Sangat Baik \\
4 & $100 \%$ & Sangat Baik \\
5 & $100 \%$ & Sangat Baik \\
6 & $100 \%$ & Sangat Baik \\
\hline Rata-Rata & \multicolumn{2}{c}{$94 \%$ (Sangat Baik) } \\
\hline
\end{tabular}


Berdasarkan Tabel 7 di atas diketahui bahwa perangkat pembelajaran berupa LKS yang dikembangkan terdapat pada kategori baik. Dengan demikian perangkat pembelajaran tersebut dapat dikatakan praktis.

\section{Analisis Data Hasil Tes Kemampuan Koneksi Matematis}

Kriteria Ketuntasan Minimal (KKM) pada mata pelajaran matematika di kelas VII MTsN 2 Kota Bima ebesar 75, sehingga dikaatakan tuntas apabila siswa mendapat nilai 275 . Adapun hasil tes kemampuan koneksi matematis siswa dapat dilihat pada Tabel 8 berikut.

Tabel 8. Hasil Tes Kemampuan Koneksi Matematis

\begin{tabular}{cc}
\hline Skor & Materi Aritmatika sosial \\
Rata-rata & 78 \\
Nilai Tertinggi & 92 \\
Nilai Terendah & 50 \\
Jumlah Siswa Yang Tuntas & 18 \\
Persentase Ketuntasan & $78,2 \%$ \\
\hline Kategori & Baik \\
\hline
\end{tabular}

Berdasarkan Tabel 8 di atas rata-rata persentase hasil tes kemampuan koneksi matematis siswa sebesar $78,2 \%$ dan berada pada kategori baik. Dengan demikian dapat disimpulkan bahwa soal kemampuan koneksi matematis dengan pendekatan BBL dikatakan efektif. Adapun kesulitan siswa dalam menyelesaikan soal tes tersebut yaitu pada penggunaan matematika dalam kehidupan sehari-hari. Hal ini senada dengan hasil penelitian (Andriani \& Nurjaman, 2018) bahwa pada indikator menggunakan kehidupan sehari-hari siswa merasa kesulitan, dan indicator yang paling tinggi adalah mencari hubungan antar representasi dan prosedur. Selain itu, (Ruspiani, 2000) mengungkapkan bahwa kemampuan koneksi terendah siswa ada pada kemampuan antar topic matematika.

\section{Kajian Produk Akhir}

Perangkat pembelajaran matematika SMP pada materi aritmetika sosial dengan pendekatan BBL berorientasi pada kemampuan koneksi matematis yang dikembangkan layak untuk dapat digunakan sebagai salah satu perangkat pembelajaran matematika yang memenuhi kualitas valid, praktis, dan efektif. Diantaranya perangkat pembelajaran yang dikembangkan berupa RPP dan LKS telah memenuhi kriteria valid dengan kategori sangat baik untuk RPP dan kategori baik untuk LKS. Kualitas kepraktisan berdasarkan penilaian guru, penilaian siswa, dan observasi keterlaksanaan pembelajaran telah memenuhi kriteria praktis dengan masingmasing kategorinya sangat baik, baik, dan sangat baik. Sedangkan kualitas keefektifan berdasarkan tes kemampuan koneksi matematis menunjukkan bahwa perangkat pembelajaran yang dikembangkan telah memenuhi kriteria efektif dengan kategori baik. Hal ini sejalan dengan penelitiannya (Lestari, 2014) bahwa peningkatan kemampuan koneksi matematis siswa yangmendapatkan pembelajaran BBL lebih baik dari siswa yang mendapat pelajaran langsung. Hal ini di dukung dengan adanya perangkat pembelajaran yang memadai.

\section{Simpulan}

Berdasarkan hasil analisis dan pembahasan dapat disimpulkan bahwa perangkat pembelajaran matematika SMP yang terdiri dari RPP dan LKS tela8h memenuhi kriteria valid dengan rata-rata skor untuk RPP sebesar 193 dengan kategori sangat baik dan rata-rata untuk LKS sebesar 114 dengan kategori baik. Kualitas kepraktisan untuk skor penilaian guru sebesar 74\% (sangat baik), skor penilaian siswa 38,78\% (baik), dan persentase keterlaksanaan pembelajaran sebesar 94\% (sangat baik), telah memenuhi kriteria praktis. Kualitas keefektifan meunjukkan bahwa perangkat pembelajaran yang dikembangkan telah memenuhi kriteria efektif dengan rata-rata persentase ketuntasan tes kemampuan koneksi matematis sebesar 75\% (baik).

\section{Ucapan Terima Kasih}

Terimakasih penulis sampaikan kepada RISTEKDIKTI yang telah mendanai demi kelancaran kegiatan penelitian ini pada pendanaan Tahun 2020. Kemudian penulis juga sampaikan kepada lembaga STKIP Taman Siswa Bima, Kepala MTs Negeri 2 Kota Bima beserta guru mata pelajaran matematika kelas VII ${ }^{8}$ yang sudah 
memberikan kesempatan penulis untuk melaksanakan kegiatan penelitian, keluarga Sanawa yang sudah mendukung, serta rekan-rekan yang turut membantu dalam kelancaran kegiatan penelitian.

\section{Daftar Pustaka}

Andriani, D., \& Nurjaman, A. (2018). Analisis Kemampuan Pemahaman Konsep Materi Segitiga dan Segiempat pada Siswa SMP. Jurnal Pembelajaran Matematika Inovatif, 1(2), 1015-1026. https://doi.org/10.22460/jpmi.v1i3.219-228

Bowen, C. (2011). Resolving the Conflict: Brain-Based Learning, Best Practices, and No Child Left Behind. Perspectives In Learning, 12(1), 6.

Connell, J. D. (2009). The Global Aspects of Brain-Based Learning. Educational Horizons, 88(1), 28-39. http://www.jstor.org/stable/42923784

Craig, D. I. (2007). Applying brain-based learning principles to athletic training education. Athletic Training Education Journal, 2(Jan-Mar), 16-20.

Fitriani, A. (2019). Pengaruh Model Brain Based Learning Ditinjau dari Kemampuan Berpikir Kritis Siswa. 9(1), 6-9.

Furner, J.M \& Marinas, C. . (2013). CONNECTING GEOMETRY, MEASUREMENT, AND ALGEBRA USING GEOGEBRA FOR THE ELEMENTARY GRADES. Educational Measurement: Issues and Practice, 24, 63-72. https://doi.org/10.1111/j.1745-3992.2009.00157.x

Johnson, E. B. (2010). Contextual teaching and learning: Menjadikan kegiatan belajar mengajar mengasyikkan dan bermakna (Terjemahan Setiawan Ibnu). Bandung: Kaifa (Buku Asli Diterbitkan Tahun 2002).

Kapadia, R. H. (2014). Level of Awareness about Knowledge, Belief and Practice of Brain based Learning of School Teachers in Greater Mumbai Region. Procedia - Social and Behavioral Sciences, 123, 97-105. https://doi.org/10.1016/j.sbspro.2014.01.1402

Kaur, J. (2013). Effectiveness of Brain Based learning Strategies on Enhancement of Life Skills among primary school students with internal and external Locus of Control. International Journal of Advancements in Research $\mathbb{E}$ Technology, 2(6), 128-143.

Klinek, S. R., \& Indiana. (2009). Brain-based Learning: Knowledge, Beliefs, and Practices of College of Education Faculty in The Pennsylvania State System of Higher Education. Vasa, May, 1-188.

Lestari, E. (2014). IMPLEMENTASI BRAIN-BASED LEARNING UNTUK MENINGKATKAN KEMAMPUAN KONEKSI DAN KEMAMPUAN BERPIKIR KRITIS SERTA MOTIVASI BELAJAR SISWA SMP. Jurnal Pendidikan UNSIKA, 2(1), 1042-1055.

Linto, R. L., Elniati, S., \& Rizal, Y. (2012). Kemampuan koneksi matematis dan metode pembelajaran quantum teaching dengan peta pikiran. Jurnal Pendidikan Matematika, 1(1), 83-87. https://doi.org/10.13989/j.cnki.0517. 6611.2015 .10 .011

Rohendi, D., \& Dulpaja, J. (2013). Connected Mathematics Project (CMP) Model Based on Presentation Media to the Mathematical Connection Ability of Junior High School Student. 4(4), 17-22.

Ruspiani. (2000). Kemampuan Siswa dalam Melakukan Koneksi Matematika. Tesis. SPS UPI Bandung. https://doi.org/10.1016/j.sbspro.2014.01.1217

Siercks, A. M. Y. M. (2012). UNDERSTANDING AND ACHIEVING BRAIN-BASED INSTRUCTION IN THE ELEMENTARY CLASSROOM : A QUALITATIVE STUDY OF STRATEGIES USED BY TEACHERS by. 2012. 